\title{
HOUSEHOLD WASTE MANAGEMENT IN MEDAN CITY
}

\author{
Mutia Arda ${ }^{1}$, Delyana Rahmawany Pulungan ${ }^{2}$, Dewi Andriany ${ }^{3}$, Yayuk Hayulina ${ }^{4}$ \\ 1,3,4 Universitas Muhammadiyah Sumatra Utara, Indonesia \\ 2 Sekolah Tinggi Ilmu Pertanian, Agrobisnis Perkebunan, Indonesia
}

Corresponding Author: delpulungan@stipap.ac.id

\begin{abstract}
The main problem in the solid waste sector in Medan City is the large number of illegal dumping. This study is to obtain an overview of the waste management that has been carried out so far, to inventory the problems of waste management system, to design a waste management model, and to provide recommendations for waste management system. This research used descriptive qualitative method. Based on the SSK instrument, it was known that the diagram of the waste sanitation system in Medan City had 6 categories. There were 18 villages in Medan City at very high risk category, 7 villages in the high-risk category, 51 villages at moderate risk category, and 75 villages at low risk category. Waste zoning in Medan City consists of 4 zones. Based on SWOT analysis which determine the objectives, targets and strategies for developing solid waste management in Medan City was in the fourth quadrant, it was a defensive strategy. The position of internal and external factors in the solid waste sub-sector in this quadrant showed that weaknesses and threats were more dominant than strengths and opportunities.
\end{abstract}

Keywords: waste management, public awareness, solid waste problem

\section{INTRODUCTION}

Garbage is a crucial problem faced by almost all areas in Medan City. The main problem in the waste sector in Medan City is that there are still many illegal dumping. This is because the level of awareness of the population is still lacking where there are still many people who do not throw garbage in its place. This is related to the high production of household (domestic) waste which is obtained from the calculation results that the waste generated every day reaches 1,500 tons. In detail, 48 percent is organic waste and 52 percent is inorganic waste. The amount of this waste is expected to continue to grow, where the annual growth rate is 4 percent. Piles of garbage that disturb the health and beauty of the environment are a type of pollution that can be classified as social environmental degradation. Organic waste or biodegradable waste is usually the largest part of household waste. This way of handling waste should be done by minimizing the generation of urban waste, namely reducing the amount of waste, recycling and utilizing waste that is still useful.

The rapid development of the population in the city of Medan cannot be separated from the influence of various advances in technology, transportation and so on. This is a fact that Medan City is the most efficient and effective location for productive activities. Population growth, changes in consumption patterns, and people's lifestyles have increased the amount of waste generation, types, and diversity of waste characteristics. The biggest waste generation in Medan Deli District which is KIM (Medan Industrial Area) is 131.90 tons/day. The smallest waste generation in Medan Baru District is 28.96 tons/day.

Based on the conditions mentioned above, it is necessary to design a waste management management model in Medan City so that it is hoped that later all sources of waste generation can be served so that management problems are handled properly. The purpose of this study is to design a model of waste management, especially household waste in the Medan City area. While the specific 
objectives are to map the level and area of waste management services that have been carried out at each source of waste generation in Medan City and take an inventory of the condition of facilities and infrastructure related to waste disposal services in Medan City, as well as design a waste management management model.

\section{IMPLEMENTATION METHOD}

This research is descriptive research. Descriptive research types generally do not require a hypothesis so that in the research step there is no need to formulate a hypothesis. In descriptive research there are two groups of data, namely qualitative data and quantitative data. Qualitative data is described in words or sentences, while quantitative data is in the form of numbers resulting from calculations or measurements.

The data used in this study are primary data and secondary data. Primary data were obtained through direct interviews with the research targets by providing a list of structured questions in the form of questionnaires to respondents and interviews with relevant agencies regarding waste management facilities and infrastructure. While secondary data were obtained from various related agencies, including the Central Statistics Agency, the Medan City Sanitation Service in the form of policy documents, solid waste data from the sub-districts in Medan City, publication of research results and various references related to this research and used to identify strengths, weaknesses, opportunities and threats.

\section{RESULTS AND DISCUSSION}

Based on the data obtained, it is known that the population of Medan City in 2020 reaches $2,264,145$ people and the ratio of waste generation / person / day is 3 liters equivalent to an average waste weight of $0.7 \mathrm{Kg}$ / person, so the total waste of Medan City is $6,792 \mathrm{~m} 3 /$ day or 1,585 tons/day. Meanwhile, only $80 \%$ of the waste served or $5,434 \mathrm{~m} 3 /$ day or 1268 tons/day. The composition of Medan city waste based on weight $\%$ of waste generation data from the Central Statistics Agency includes $48.2 \%$ organic waste and $51.8 \%$ inorganic waste.

The total volume of waste transported by garbage trucks to the Final Waste Management Site (TPSA) per day is $75 \%$ of the served waste where this reduction is played by $3 \mathrm{R}$ TPS, recycling stalls, waste banks and so on. The estimated waste that arrives and is processed at the TPA per day is $4,076 \mathrm{~m} 3$ or 951 tons.

For more details, the following in Figure 2 is a diagram of the Waste Management Sanitation System which contains information related to the current solid waste system and the scope of its services in the city of Medan which consists of 6 categories, among others: waste is sorted directly by scavengers, waste is disposed of at the TPS and lifted by dump trucks. transported to TPST $3 \mathrm{R}$ and ended up at TPA (Final Disposal Site), garbage picked up by dump trucks was transported to TPST 3R and ended at TPA, garbage transported by tricycles/motorcycles was dumped into TPS picked up by dump trucks and ended up at TPA, garbage dumped to TPS was picked up by dump truck and ends up in the TPA, the garbage is picked up by a dump truck and ends up in the TPA. 


\section{ORFAI JOURNAL Multidiciplinary Output Research For Actual and International Issue}

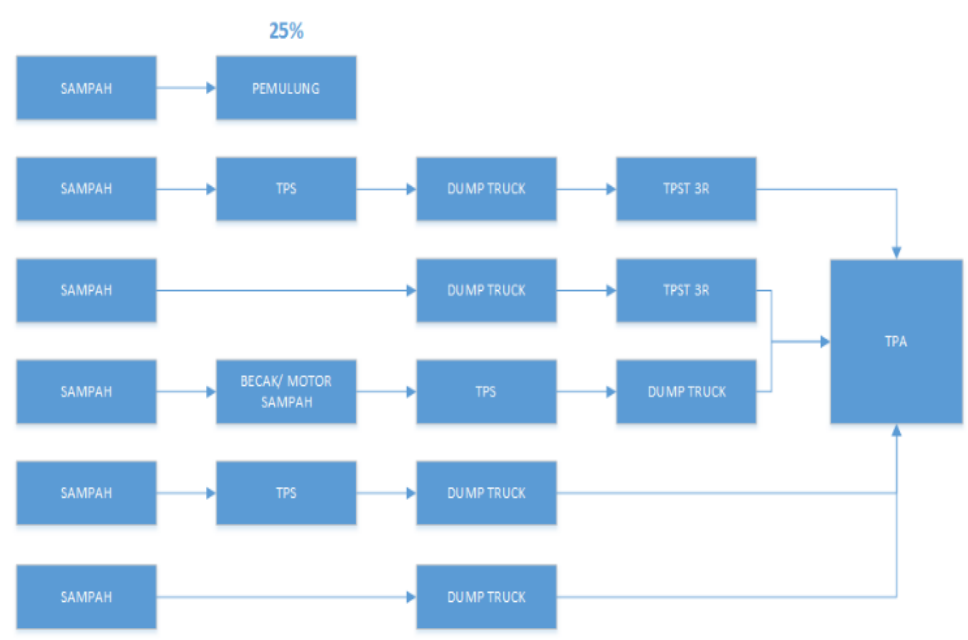

Figure 1. Domestic Solid Waste Sanitation System Diagram

Garbage piles per sub-district in Medan City in 2020 that the volume of waste generation is $1500-1700$ tons/day. The largest volume of waste generation is in Medan Deli District, which is $8.2 \%$ and the lowest volume is Medan Baru District, which is $1.8 \%$. Coverage of Access and Solid Waste Service System in Medan City that the volume of waste transported to the TPA is as much as $5,434 \mathrm{~m} 3 /$ day or about $80 \%$ of the total waste generated.

The volume of waste generated every day in the city of Medan is very large, namely 6,792 $\mathrm{m} 3 /$ day or approximately 1700 tons/day. Waste management efforts carried out in various areas in Medan City by a number of housings, markets, offices and schools show very small numbers, namely that each agency is only able to process $2-10 \mathrm{~m} 3$ of waste per month in addition to composting efforts carried out by TPA officers who only able to process $15 \mathrm{~m} 3$ of waste per month. Meanwhile, 3R waste management at TPST or 3R TPS also seems to be still very minimal. Only 4 sub-districts have 3R TPS, this means that there is still a lot of need for TPST or other 3R TPS in an effort to reduce, reuse or recycle waste that is considered suitable for use, namely the districts of Medan Timur, Medan Marelan, Medan Belawan,

The number of waste transportation facilities and infrastructure is still inadequate so that this has an impact on the non-optimal transportation of public waste, especially on problems of transportation management and waste recycling which result in delays and overload of waste in TPSTPS scattered in Medan City. Furthermore, based on the results of data processing of the Medan City SSK Instrument and then an adjustment discussion with the Medan City Sanitation Working Group showed that the urban village categories in Medan City based on the magnitude of the impact of solid waste risk in general are as follows.

a. Kelurahan is categorized as very high risk (red). The sub-districts included in this category are 18 sub-districts throughout the city of Medan.

b. Villages in the high-risk category (yellow). Villages that fall into this category are 7 Kelurahans in all areas in Medan City.

c. Kelurahan is categorized as moderate risk (green). Villages that fall into this category are 51 Kelurahans in all areas in Medan City.

d. Kelurahan is categorized as very low risk (blue). The sub-districts included in this category are 75 sub-districts throughout the city of Medan.

Sub-districts that fall into the category of very high-risk and high-risk areas are generally urban villages with high density and poverty levels relative to other urban villages in Medan City. This shows that environmental conditions and poverty contribute to the vulnerability of these kelurahan into very high risk and high-risk areas. The following table will show the Waste Risk Areas in Medan City. 
Household Waste Management In Medan City

DOI: $10.54443 /$ morfai.v1i2.70

Table 1. Waste Risk Areas in Medan City

\begin{tabular}{|c|c|c|c|}
\hline No & Area Berisiko*) & $\begin{array}{c}\text { Wilayah Prioritas } \\
\text { Persampahan }\end{array}$ & Kecamatan \\
\hline 1. & $\begin{array}{l}\text { Risiko } 4 \\
\text { (Berisiko Sangat } \\
\text { Tinggi) }\end{array}$ & $\begin{array}{l}\text { 1. Kelurahan Kwala Bekala } \\
\text { 2. Kelurahan Harjosari I } \\
\text { 3. Kelurahan Sei Kera Hilir II } \\
\text { 4. Kelurahan Tanjung Mulia Hilir } \\
\text { 5. Kelurahan Titi Papan } \\
\text { 6. Kelurahan Besar } \\
\text { 7. Kelurahan Tangkahan } \\
\text { 8. Kelurahan Sei Mati } \\
\text { 9. Kelurahan Nelayan Indah } \\
\text { 10. Kelurahan Rengas Pulau } \\
\text { 11. Kelurahan Terjun } \\
\text { 12. Kelurahan Labuhan Deli } \\
\text { 13. Kelurahan Belawan P Sicanang } \\
\text { 14. Kelurahan Belawan Bahagia } \\
\text { 15. Kelurahan Belawan Bahari } \\
\text { 16. Kelurahan Belawan II } \\
\text { 17. Kelurahan Bagan Deli } \\
\text { 18. Kelurahan Belawan I }\end{array}$ & $\begin{array}{c}\text { Medan Johor } \\
\text { Medan Amplas } \\
\text { Medan Perjuangan } \\
\text { Medan Deli } \\
\text { Medan Deli } \\
\text { Medan Labuhan } \\
\text { Medan Labuhan } \\
\text { Medan Labuhan } \\
\text { Medan Labuhan } \\
\text { Medan Belawan } \\
\text { Medan Belawan } \\
\text { Medan Belawan } \\
\text { Medan Belawan } \\
\text { Medan Belawan } \\
\text { Medan Belawan } \\
\text { Medan Belawan } \\
\text { Medan Belawan } \\
\text { Medan Belawan }\end{array}$ \\
\hline 2. & $\begin{array}{l}\text { Risiko } 3 \\
\text { (Berisiko Tinggi) }\end{array}$ & $\begin{array}{l}\text { 1. Kelurahan Harjosari II } \\
\text { 2. Kelurahan Gang Buntu } \\
\text { 3. Kelurahan Gaharu } \\
\text { 4. Kelurahan Mabar Hilir } \\
\text { 5. Kelurahan Mabar }\end{array}$ & $\begin{array}{l}\text { Medan Amplas } \\
\text { Medan Timur } \\
\text { Medan Timur } \\
\text { Medan Deli } \\
\text { Medan Deli }\end{array}$ \\
\hline & & $\begin{array}{l}\text { 6. Kelurahan Pekan Labuhan } \\
\text { 7. Kelurahan Paya Pasir }\end{array}$ & $\begin{array}{l}\text { Medan Labuhan } \\
\text { Medan Belawan }\end{array}$ \\
\hline
\end{tabular}

Sub-districts that fall into this high-risk area category are generally urban villages in the CBD and there are traditional markets with a high density and poverty rate relative to other urban villages in Medan City, including areas traversed by the Belwan River, Deli River and Percut River. This shows that environmental conditions and poverty contribute to the vulnerability of the kelurahan to be included in high-risk areas for solid waste. Furthermore, the following table will present a list of urgent problems, both technical and non-technical aspects related to solid waste management in Medan City.

The urgent problems in waste management are as follows:

a. Technical Aspect

- The waste transported is not yet optimal, which is only $83 \%$ or the equivalent of $1,879,240$ residents who are served by waste transportation. This estimate of unserved waste is made possible by the large proportion of households burning waste and the many possibilities for individual and communal collection and transportation of waste carried out by the community that are not recorded by the sub-district.

- The landfill that is still operating at this time is the Waterfall TPA which is located in the Village of Falls, District of Medan Marelan. Based on observations and calculations, the unused area is 4 hectares, while the remaining life of the landfill is predicted to be a maximum of 4 years.

- The number of waste transportation facilities and infrastructure is still inadequate, this has an impact on the non-optimal transportation of public waste, especially on problems of transportation management and waste recycling which result in delays and waste overload at TPS-TPS.

- Waste recycling is still very minimal, which is about 7 units of 3R TPS, so it has not significantly reduced the volume of residents' waste. 
b. Non-technical Aspect

- The relatively limited budget allocation and waste financing is around $4.36 \%$ of the direct expenditure of the Medan City Regional Budget. Then, the involvement of the community and the private sector is not optimal in waste management

- regulations or local regulations on waste management need to be reviewed and also revised the Waste Master Plan

- Public awareness is still low to carry out environmentally friendly waste management, or to separate waste based on its type.

\subsection{Waste Zone in Medan City}

The analysis of the determination of the zoning and sanitation system for solid waste in the city of Medan, obtained an illustration that in the scope of the kelurahan the waste management system in the city of Medan is categorized into 4 (four) zoning classifications, as follows;

\section{Zone 1.}

Is an area characterized by a relatively high level of waste processing services or a population whose waste is transported by $100 \%$, not a CBD area, population density $<25$ people/ha, and does not have a traditional market. This area is addressed by mid-term handling in the next 5 years. This area should be served by an indirect collection system; house to house with garbage carts and garbage motorbikes or take them directly to the container/TPS. This zone or area covers 1 subdistrict in Medan Polonia, namely one sub-district, namely Suka Damai Village

\section{Zone 2.}

Is an area characterized by the level of waste processing services or a population whose waste is transported by $83 \%$, is not a CBD area, a population density of 25-100 people/hectare, has a traditional market, and is a priority area based on the level of sanitation risk. Because the area is not too crowded, business district and public places, it must be fully serviced $100 \%$ (full coverage). Areas like this can be overcome in the short term up to the next 5 years with a direct service system from the source, TPS to TPA and road sweeping services. The sub-districts included in this zone are Medan Tuntungan, Medan Johor, Medan Maimun, Medan Polonia, Medan Baru, Medan Sunggal, Medan Labuhan, Medan Marelan and Medan Belawan.

\section{Zone 3}

Is an area characterized by the level of waste processing services or residents whose waste is transported by $80 \%$, or below the average level of waste services in Medan City, is not a CBD, population density $>100$ people/hectare, has a traditional market, and is a priority area based on the level of sanitation risk. Because it is a priority area or area based on the level of sanitation risk, the level of service must be increased and addressed in the short term up to the next 5 years with a direct service collection system, namely house to house with dump trucks and indirect collection system, namely house to house with carts. and garbage motors. This area can also be developed to manage waste properly in accordance with health requirements and the $3 \mathrm{R}$ concept and expand the provision of $3 R$ TPS.

\section{Zone 4}

Is an area characterized by the level of waste processing services or a population whose waste is transported by $87 \%$, is a CBD area, population density > 100 people/hectare, has a traditional market, and is a priority area based on the level of sanitation risk. Because it is a priority area or area based on the level of sanitation risk, the level of service must be increased and addressed in the short term up to the next 5 years with a direct service collection system, namely house to house with dump trucks and indirect collection system, namely house to house with carts. and garbage motors. This area can also be developed to manage waste properly in accordance with health requirements and the $3 R$ concept and expand the provision of 3R TPS. The sub-districts included in this zone are: Medan Johor, Medan Amplas, 


\subsection{SWOT Analysis}

To identify the key success factors and formulate this strategy, SWOT (Strength, Weakness, Opportunity, and Threat) analysis was used. SWOT analysis which consists of internal and external analysis, is used to determine and analyze the intended strategy, because internal and external factors in development have a high degree of correlation and combination to influence each other.(Terry, 2014).

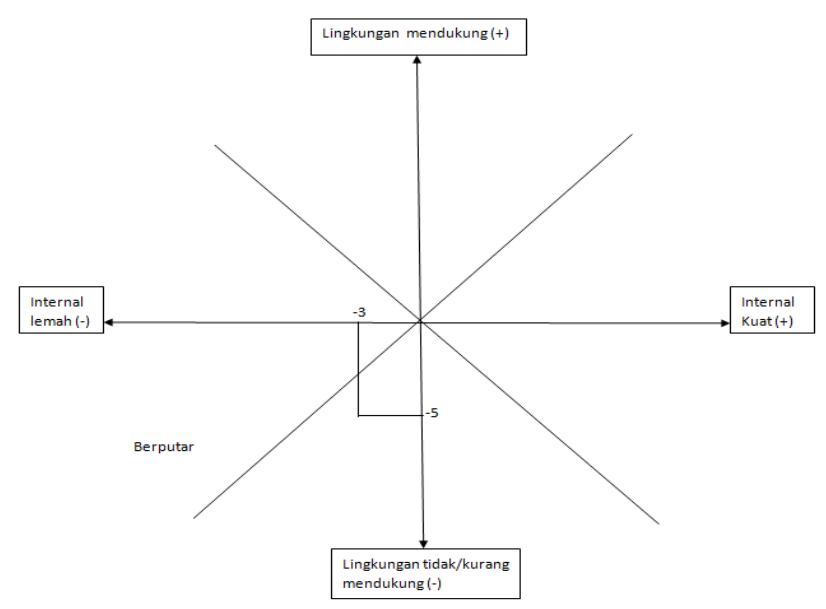

Figure 2. Waste SWOT Analysis

Based on the results of the SWOT calculation, the waste sub-sector of Medan City is in Quadrant four, namely Weak Internal and Unsupportive Environment, with the result that the value of the difference between Strengths and Weaknesses on Internal factors shows a negative value and the value of the difference between Opportunities and Threats on External factors also shows The negative value is in the position, so the strategy that will be developed to overcome the strategic issues that arise in order to achieve the target of the solid waste subsector is a defensive strategy. This strategy is also known as minimizing weaknesses to defend against threats. The strategies carried out by the Medan City government in managing household waste are presented in table 2 .

The concept of household waste management that can be adopted by the Medan City government based on the SSK instrument and the strategy generated from the SWOT analysis above is environmentally sound waste management to prevent the impact. One way to overcome this is to change the pattern of production and consumption that is unbalanced (unsustainable). This implies an integrated life cycle management concept, which represents an opportunity to combine development with environmental protection. So the framework of action should be determined based on a hierarchy of objectives and focused on 4 programs related to waste, namely:

a. Reducing the amount of waste (minimising waste)

b. Increase environmentally friendly waste reuse and recycling.

c. Promote environmentally friendly landfills and processing sites.

d. Expanding the range of waste services

The four programs above are related and must be mutually supportive and integrated to produce a comprehensive and environmentally responsive framework for municipal solid waste management. Likewise, the private sector and community groups are also involved in implementing the program. 


\section{OMRAII JOURNAL Actual and International Issue}

Table 2. Waste Subsector Goals, Targets, and Strategies

\begin{tabular}{|c|c|c|c|}
\hline \multirow[b]{2}{*}{$\begin{array}{c}\text { Tujuan } \\
\text { (1) }\end{array}$} & \multicolumn{2}{|c|}{ Sasaran } & \multirow[b]{2}{*}{$\begin{array}{c}\text { Strategi } \\
\text { (4) }\end{array}$} \\
\hline & $\begin{array}{c}\text { Pernyataan } \\
\text { Sasaran } \\
\text { (2) }\end{array}$ & Indikator Sasaran & \\
\hline \multirow[t]{2}{*}{$\begin{array}{l}\text { Meningkatkan } \\
\text { persentase } \\
\text { sampah yang } \\
\text { terangkut atau } \\
\text { tertangani di } \\
\text { perkotaan }\end{array}$} & $\begin{array}{l}\text { Terlayaninya } \\
\text { keseluruhan } \\
\text { wilayah }(100 \%) \\
\text { dengan } \\
\text { pengangkutan } \\
\text { sampah secara } \\
\text { kontinyu }\end{array}$ & $\begin{array}{l}100 \% \text { wilayah } \\
\text { terlayani } \\
\text { pengangkutan } \\
\text { sampah dengan } \\
\text { truk. }\end{array}$ & $\begin{array}{l}\text { 1. Mendorong penyediaan fasilitas } \\
\text { pengangkutan sampah untuk } \\
\text { memenuhi jumlah kebutuhan. } \\
\text { 2. Optimalisasi pengangkutan } \\
\text { sampah langsung dan tidak } \\
\text { langsung. }\end{array}$ \\
\hline & $\begin{array}{l}\text { Berkurangnya } \\
\text { volume sampah } \\
\text { terangkut ke } \\
\text { TPA sebesar } \\
10 \%\end{array}$ & $\begin{array}{l}531,6 \mathrm{M}^{3} / \text { hari } \\
\text { sampah tereduksi } \\
\text { dengan pada TPS } \\
\text { 3R }\end{array}$ & $\begin{array}{l}\text { 1. Menyiapkan stimulus terkait } \\
\text { pengurangan sampah } \\
\text { 2. Memperluas penyediaan sarana } \\
\text { TPS 3R dan advokasi serta } \\
\text { sosialisasi pengurangan sampah. } \\
\text { 3. Meningkatkan pengetahuan dan } \\
\text { kesadaran warga terkait } \\
\text { pengelolaan sampah TPS3R }\end{array}$ \\
\hline $\begin{array}{l}\text { Meningkatkan } \\
\text { komitmen } \\
\text { pendanaan } \\
\text { APBD atas } \\
\text { persampahan }\end{array}$ & $\begin{array}{l}\text { Meningkatnya } \\
\text { komitmen } \\
\text { pendanaan } \\
\text { APBD: }>5 \%\end{array}$ & $\begin{array}{l}\text { Pembiayaan } \\
\text { persampahan dari } \\
\text { belanja langsung } \\
\text { naik menjadi } \geq 5 \%\end{array}$ & $\begin{array}{l}\text { 1. Optimalisasi pendanaan DAU } \\
\text { untuk subsektor persampahan. } \\
\text { 2. Optimalisasi DAK Sanitasi dan } \\
\text { DAK LH. } \\
\text { 3. Optimalisasi } \\
\text { persampahan. } \\
\text { 4. Advokasi dan sosialisasi kepada } \\
\text { TAPD Pemko Medan dan } \\
\text { Banggar DPRD terkait } \\
\text { pembiayaan Dusibusi } \\
\text { persampahan. }\end{array}$ \\
\hline
\end{tabular}

\section{CONCLUSION}

Waste problems in Medan City include technical and non-technical problems, technical aspects include: the transported waste is not yet optimal, namely only $83 \%$ are served by waste transportation, TPA is operated by open dumping, the number of facilities and infrastructure for transporting waste is still inadequate, recycling waste is still very minimal, which is about 7 units of 3R TPS so that it has not significantly reduced the volume of residents' waste. Problems in the non-technical aspects of solid waste in the city of Medan include: the relatively limited budget allocation and financing of solid waste, which is around $4.36 \%$ of the direct expenditure of the Medan city budget, regulations or local regulations concerning waste management need to be reviewed and revised as well as the waste master plan, the low awareness of the community to manage waste. environmentally sound waste, or separating waste by type. Then based on a SWOT analysis to determine the Objectives, Targets and Strategies for the development of Waste Management in Medan City, it is in the fourth quadrant, namely a defensive strategy. The position of internal and external factors in the solid waste sub-sector in this quadrant indicates that weaknesses and threats are more dominant than strengths and opportunities.

\section{REFERENCES}

Central Statistics Agency. (2019). Medan City in Numbers. Medan: Central Bureau of Statistics.

Dwiyanto. (2011). Model of Increasing Community Participation and Strengthening Synergy in Urban Waste Management. Journal of Development Economics, 239-256.

Kamali, A. (2012). Study of Final Disposal Sites (TPA) with Environmental Economic Approach (Case Study of TPA Jatibarang Semarang). Semarang: UNDIP Postgraduate Program. 
Rahardyan, B., \& Widagdo, AS (2015). Improving Urban Waste Management Through Recycling Development. Jakarta.

Slamet, J. (2012). Environmental Health. Yogyakarta: Gadjah Mada University Press.

Syafrudin. (2014). Community Based Waste Management. Proceedings of the Interactive Discussion on Integrated Urban Waste Management. Semarang: Master Program in Environmental Science UNDIP.

Syafrudin, \& Priyambada, IB (2011). Solid Waste Management. Semarang: Environmental Engineering Study Program, Faculty of Engineering UNDIP.

Terry. (2014). Introduction to Management. Jakarta: Four Salemba.

\section{Notes:}

Thank's A Lot To Radja Publica As The Head Officer Of Ijebas Journal Who Has Facilitated The Process Of Publishing This Scientific Article And Also Especially To Lppm Malikussaleh University. Who Is Willing To Cooperate In The Process Of Publishing Articles About Household Waste Management in Medan City. 